\title{
CINCINNATI'S TRACTION PROBLEMS
}

\author{
BY ELLIOTT HUNT PENDLETON ${ }^{1}$
}

Cincinnati

$\mathrm{H}^{\mathrm{n}}$

ENRY T. HUNT was elected mayor of Cincinnati in November, 1911, and assumed office January 1,1912. Before entering upon his duties Cincinnati's new chief executive formulated a program of objects to be accomplished during the two-year term for which he had been chosen. Improvement of the city's street railway service and the preparation of plans for securing rapid transit facilities-urban as well as interurban-formed a part of his constructive program.

The benefits that would result from better transportation facilities were fully appreciated by Mayor Hunt. In his judgment such facilities were needed not merely for the purpose of promoting the growth and material prosperity of the city, but in order to render possible the accomplishment of much more important ends, namely, the solution of Cincinnati's serious housing problem and a saving in the cost of living to all the inhabitants of the city.

Any one who has visited Cincinnati will recall that most of its factories and business establishments are located in the lower part of the city, and that this section is bounded on the south by the Ohio River and on the north, east and west, by steep hills. The population in this lower and oldest part of Cincinnati is very dense, as a large proportion of the factory workers, and nearly all of the city's poor, live in houses and tenements that were built in this section a half a century or more ago. That quick and cheap transportation to the beautiful and encircling hills would tend greatly to relieve the congestion that now prevails in this central portion of the city is quite apparent. It is equally clear that convenient and rapid means for reaching houses built upon the upper levels of the city would contribute in no small degree to the health, comfort and happiness, of the entire community. The conservation of health, morals, comfort and happiness, was what led Mayor Hunt into the fight that he has conducted with such vigor to secure better transportation facilities for the people of Cincinnati.

In order to understand the many problems connected with the traction campaign which Cincinnati's courageous young mayor has been carrying

$1 \mathrm{Mr}$. Pendleton for many years has been a conspicuous leader in Cincinnati for higher standards of municipal life and conduct. He has been identified with the various independent movements and was in the forefront of the campaign for Mayor Hunt's election. He has been editor and publisher of The Citizens'Bulletin of Cincinnati, and since 1903 has been a member of the council of the National Municipal League. Harvard University in June, 1913, conferred upon him the degree of master of arts as a recognition of his civic work. 
on, some knowledge concerning the development of Cincinnati's street railway facilities into the system that is in operation today is essential.

The first street railroads in Cincinnati were authorized by an ordinance passed July 1, 1859. This provided that cars with "all modern improvements" were to be run "as often as the public convenience might require," under the direction and regulation of the city council. Provision was also made for the sale of tickets in packages of twenty-five and that no fare should exceed 5 cents. Another provision of this ancient piece of municipal legislation was that the street railway companies were required to purchase any competing omnibus lines at a price to be ascertained by arbitration. The result of this exaction drove most of the original companies into bankruptcy.

A comparison of the rate of fare charged by the Cincinnati Traction Company today with the charges imposed by Cincinnati's old omnibus companies furnishes a forcible illustration of how great a reduction in the cost of transportation has been effected since the introduction of the street railway. The fares collected by the old omnibus lines ranged from 5 to 25 cents, and no one of their routes extended more than half the distance which passengers may ride for a nickel today.

The city council on July 13, 1859, determined upon six street car routes, and on the same day franchises to operate cars over these lines were granted to six different companies. These routes began at some fairly central point and extended but a short distance. into the various sections of the lower part of the city. One of these grants was made to the Cincinnati Street Railway Company, and the first street car in the city was run by this company, September 14, 1859. After the six original routes had been constructed, other short and independent lines were established in rapid succession and without regard to any general system. These short and independent routes finally numbered twenty-five. Extensions of old routes were also granted, from time to time, and authority to collect higher fares than 5 cents was then given.

For the purpose of saving time consumed in ascending, in the horse drawn cars of that day, the very steep hill that led to the residential district known as Mt. Auburn, there was constructed in 1872, an inclined plane from the lower level of the city to the top of the hill. This elevator was looked upon as an experiment and was not expected by many to prove a success. It became quite popular, however; owing to the great saving of time which it effected; and as extra fares. were. collected from those who used it, the venture proved a financial success. Five other inclined planes were subsequently constructed to the tops of the.other bills that surround Cincinnati.

When Cincinnati's inclined planes were first built, passengers were required to transfer to and from the street cars at both the foot and top 
of the hills. Within a short time thereafter, however, large trucks were constructed upon which to run the cars and lift them up, thus rendering the removal of passengers at the foot and top of the hills unnecessary. Serious accidents occurred on some of these inclined planes and proved very costly to the companies. A few of these elevators have been abandoned, but several of them are still operated as they afford the only practical means of furnishing certain sections of the city with street railway service.

The problem of climbing Cincinnati's hills led later to the construction of cable roads. Motive power of this character was adopted by three different companies. At very large expense cable roads were constructed to several of the city's principal residential sections on the hilltops. Within a few years, however, the demands for better service necessitated their abandonment and the substitution of electric motive power. These changes in construction and equipment made heavy drains upon the funds of the various companies. The result was that nearly all of the original companies either failed or went out of business. All of these lines were taken over and operated by the Cincinnati Street Railway Company.

In the early part of 1896 there were but four traction companies operating in Cincinnati. These companies were entirely independent of each other and no transfer privileges were granted. The rates of fare from outlying districts to the central part of the city varied from 5 cents to 15 cents. Passengers desiring to reach some point on the opposite side of the city were required to pay an additional fare. Under such conditions it is but natural that the people of Cincinnati became thoroughly dissatisfied with the existing system and that lower fares and universal transfers were vigorously demanded. This agitation resulted in the passage of a law-known as the Rogers law-permitting the consolidation of various lines in any Ohio municipality. The Rogers law authorized the board of administration, or council of any city, to grant to the consolidated company a fifty-year franchise, at a rate of fare not exceeding 5 cents for the first twenty years of the term. At the end of that period a readjustment of the rate of fare for the ensuring fifteen years was to be made, when the rate of fare was again to be revised for the last fifteen years of the fifty-year grant.

Shortly after the passage of the Rogers law a merger of the three other companies with the Cincinnati Street Railway Company was effected. A contract was then entered into between the city and that company, in which there was granted to it a right or franchise to operate cars, upon certain terms and conditions, in and upon designated streets, for a term of fifty years. This contract provided that cars should be run in such numbers and as frequently as the public convenience might require, and at a rate of fare not exceeding 5 cents during the first twenty years of 
the term. Provision was also made that transfers should be gianted, without extra charge, to passengers desiring to be conveyed, in the same general direction, from one part to any other part of the city. It was also provided that readjustments of the rate of fare, and of practically all of the other terms o the contract, should be made at the end of twenty years, and at the expiration of thirty-five years, from the beginning of the fifty-year grant. For the privilege of using the streets, the company was required to pay to the city, annually, 5 per cent of its gross receipts. Car license fees were also to be collected. The payment of car license fees was subsequently waived, in consideration of the company's agreement to pay to the city, annually, 6 per cent of its gross receipts. This payment amounted, in 1912, to about $\$ 315,000$.

At the time of its enactment and, in fact, ever since the passage of the Rogers law, there has been great misunderstanding regarding its various provisions. It was at first believed by the citizens generally that by the contract entered into with the traction company the people of Cincinnati would be required to pay 5 cent fares throughout the entire term of the fifty-year grant. The provisions of the law which provided for revisions of the rate of fare at stated periods, and which in many other ways safeguarded the interests of the public, were not understood by the great body of the citizenship. For these reasons indignation over the enactment of the law rose to a high pitch. Charges of bribery in connection with the passage of the measure were freely made. No indictments, however, resulted. The feeling against Senator Foraker, who was then acting as counsel for the street railway company, was very bitter, as it was generally believed that it was through his influence with the general assembly - the same body that had just chosen him to be one of Ohio's representatives in the United States senate- that the passage of the law had been brought about.

The Rogers law was repealed by the next general assembly and Cincinnati was the only city that availed itself of the provisions of the measure during the period that it was in force. The constitutionality of the act was attacked, but the law was declared valid by the supreme court of the state, and street railway service has been furnished to the people of Cincinnati, during the past seventeen years, under the contract entered into in 1896 in pursuance of the provisions of the Rogers law.

In considering Cincinnati's complicated traction controversy, the fact should be borne in mind that at the time the new fifty-year franchise was granted to the Cincinnati Street Railway Company, in 1896, the average unexpired term of the franchises then held by the company was about seventeen years.

In 1901 the Cincinnati Street Railway Company leased its entire property to the Cincinnati Traction Company, a new company that had been 
organized for the purpose of operating the entire street railway system. Under the terms of this lease the operating company agreed to pay a rental amounting to 5 per cent at first, but advancing gradually to 6 per cent, on the outstanding capital stock of the lessor company. The 6 per cent rate was reached in 1905 . The dividends that had been previously declared by the lessor company had never exceed 5 per cent, but in accordance with the terms of the new lease its stockholders have enjoyed dividends at the rate of 6 per cent since 1905.

The story of this lease transaction is as follows: Owing to the constant demands of the public for improved service and the consequent increasing difficulty experienced by the Cincinnati Street Railway Company in earning 5 per cent on its capital stock, its managers grew tired of the business and took up the matter of leasing the company's entire system. The proposition was submitted to the Widener-Elkins syndicate, of Philadelphia. Prior to this solicitation, the gentlemen composing this syndicate had entertained no thought of making any investment in Cincinnati traction property. They consented to consider the proposition, however, and entered upon an investigation of the Cincinnati traction system with but little idea of consummating any lease of the property. The result of the investigation, however, disclosed that the methods of operation pursued by the old company were antiquated, and that by the introduction of up-to-date and efficient management, savings could be effected and the property be made to pay. Subsequent negotiations resulted in the lease above referred to. One of the provisions of this lease was that the Cincinnati Traction Company should expend at least $\$ 2,000,000$ in improvements.

The Cincinnati Traction Company was organized with a capital stock of only $\$ 2,000,000$, but a holding company, called the Ohio Traction Company, was subsequently formed, capitalized at $\$ 17,000,000 ; \$ 8,500,000$ of this was represented by preferred stock and an equal amount by common stock. This company sold its preferred stock at about $\$ 85$ a share, including a bonus of an equal amount of common stock. The company was also bonded for $\$ 2,500,000$. These bonds were sold for very nearly par. The funds realized from both stock and bonds went into betterments of the system, with the exception of $\$ 1,000,000$ that was used to construct an office building on one of the city's most prominent corners and about $\$ 283,000$ that was invested in a car building company and in the purchase of the Cincinnati zoölogical garden. As the Ohio Traction Company took over the entire $\$ 2,000,000$ capital stock of the Cincinnati Traction Company, the Ohio Traction Company is virtually the lessee company.

The outstanding capital stock of the lessor company-the Cincinnati Street Railway Company-is $\$ 18,738,950$ and it is upon this amount that 
the lessee company is obligated to pay 6 per cent interest annually. By adding to this capitalization of the lessor company the sum of $\$ 9,727,000$ expended in betterment to the system by the lessee company, a total present valuation of $\$ 28,465,950$ is produced.

As there was practically no public protest against the consummation of the lease to the Cincinnati Traction Company the transaction was promptly approved by the city council.

Notwithstanding the extensive betterments made by the lessee company there were still many complaints on the part of citizens regarding the service rendered. Most of these complaints were directed against the overcrowding of the cars during the rush hours. The company's answer to these complaints was that it was impossible to run more cars over the tracks in the congested district during such periods. This was, to a very great extent, true. What was needed was a new routing of the lines in the congested districts. No attempt to apply this remedy however had ever been made by any city administration during the years that Boss Cox dominated every department of the government of Cincinnati.

When Mayor Hunt assumed office he devoted his energies at once to securing improved street railway service. In order to deal with the problem intelligently he recommended the employment of a traction expert to make a careful survey of conditions and to report upon a comprehensive system of rerouting and also as to the number of cars that should be run over each line, in orden to produce adequate and satisfactory service. Council made an appropriation for the purpose and R. W. Harris, of Milwaukee, considered the best expert in the country for the task, was employed to investigate and report as to what should be done. Mr. Harris with a large corps of assistants spent several months studying the situation and, based upon some six million observations relative to existing conditions, made a comprehensive report as to rerouting and as to the number of additional cars needed.

The report he submitted recommended the addition of sixty-five new cars at once. The traction company not only consented to comply with this recommendation, but ordered seventy-five additional cars. These new cars, of the most improved type, have now been in operation for several months. The traction company also expressed its willingness to reroute its lines as soon as the council should pass the necessary rerouting ordinance. When Mr. Harris' rerouting plan came before the council, however, many who owned property along the old lines began to protest against the changes therein proposed. After months of public discussion, and with but few changes in the plan recommended, the rerouting ordinance was finally passed and the traction company is now preparing to install the new system at the earliest possible date.

During this rerouting discussion, Mayor Hunt realized more than ever 
that Cincinnati was greatly in need of a rapid transit urban, as well as interurban, service. The interurban service which Cincinnati now has is unsatisfactory, because all interurban cars must use the same tracks, within the limits of the city, as are used by the cars of the local traction system. On this account, not only has the problem of congestion been made more difficult, but much more time than should be consumed is required for the transportation of interurban passengers to the heart of the city.

To deal intelligently with the city's rapid transit problem Mayor Hunt appointed a rapid transit commission. The members of this commission raised a fund and employed Bion J. Arnold, of Chicago, a traction engineer of national reputation, to make a survey and to recommend the best plan Cincinnati could adopt to secure adequate rapid transit service. Mr. Arnold, after devoting several months to the study of the local situation, reported his conclusions. He advocated the construction of a loop encircling the city's hills, parts of which were to be built underground and parts on the surface and overhead. The report was considered by civic and business organizations and met with general approval; but Mr. Arnold's estimate that the project would cost about $\$ 7,000,000$ seemed to be a stumbling block to many. In order to meet the objections relative to cost which had been raised, Mayor Hunt entered into negotiations with the traction company for the purpose of inducing it to agree, in the event of the construction of the proposed rapid transit loop by the city, to lease and operate the system, and to pay as rental for the property an amount sufficient to pay interest and sinking fund upon the cost of the improvement. The mayor's proposition also provided that the company should grant as many transfers to and from its existing lines as might be necessary to enable passengers to ride from any one point to any other point, in the same general direction, within the limits of the city. In connection with and as a part of this new arrangement Mayor Hunt proposed to effect a resettlement with the traction company of its existing franchise by the substitution of an indeterminate franchise in place of its fifty-year grant, through an agreement as to the valuation of the system and the amount of interest thereon the company should be allowed to earn. Provisions relative to fares and regulation of service were also to be fully provided for in the new contract.

Mayor Hunt's negotiations with the traction company were progressing favorably when they were abruptly and seriously interfered with by the introduction of a bill in the general assembly providing for the revocation of the franchise of the Cincinnati Street Railway Company. This drastic measure was fathered by Herbert S. Bigelow, a member from Hamilton County, in which Cincinnati is located. Mr. Bigelow is a Democrat of $\mathrm{th}^{\mathrm{e}}$ ultra radical type, and as municipal ownership as well as municipal 
operation of all city utilities formed a part of his platform, he had for years been waging a bitter war against the Cincinnati Traction Company. Through the passage of his revocation bill Mr. Bigelow hoped to bring about the acquisition by the city of the street railway system at a figure far below that which the city would otherwise undoubtedly have to pay for the property.

The right of the general assembly to revoke the franchise granted by the city to the street railway company was based by Mr. Bigelow on article 1, section 2, of the constitution of Ohio, which reads as follows: "No special privileges or immunities shall ever be granted that may not be altered, revoked or repealed by the general assembly."

In the opinion of Mayor Hunt and of many other lawyers of the Hamilton County bar, the clause of the constitution quoted relates to privileges and immunities granted by the state in articles of incorporation and was introduced by the framers of the constitution of 1851 for the purpose of making it perfectly clear that charters might be altered, amended or repealed, and to prevent their being construed to be contracts and, therefore, irrepealable, in accordance with the doctrine laid down by the supreme court of the United States in the Dartmouth College case. In the opinion of many able lawyers the clause in question was neither intended, nor does it apply, to the right which a city has granted to a company to run cars over some of its streets, and which formed an essential part of the contract entered into by the company with the municipality to furnish transportation to the inhabitants thereof, upon specified terms and conditions.

During the entire sixty-two years since the adoption of the clause of the Ohio constitution under consideration and prior to the introduction of Mr. Bigelow's bill, there had never been the least suggestion that the provision might be interpreted in the manner that Mr. Bigelow claims it should be construed. In this connection it is well to bear in mind that the constitution of Ohio, as well as the constitution of the United States, provides that no laws shall be passed impairing the obligation of contracts.

In the case of the Omaha Water Company vs. The City of Omaha, ${ }^{2}$ the court held as follows:

Neither the power of a municipality to contract with a third party for the construction and operation of waterworks, street railways or other public utilities, nor the right of such a party under such a contract, constitutes a special privilege or immunity within the meaning of those terms in section 16, article 1, of the constitution of Nebraska which prohibits the legislature from "making any irrevocable grant of special privileges and immunities."

1147 Fed. Rep., page 1. 
The power to alter or repeal general laws under which corporations have been organized, reserved by section 1 , article xiii, of the constitution of Nebraska, 1875, is limited by section 18, article $i$, of the same constitution, which forbids the passage of any law impairing the obligation of contracts, and it does not reserve to the legislature the power to destroy or impair the contract of third parties with such corporations.

The foregoing decision was practically affirmed by the supreme court of the United States by the denial of a writ of certiorari on December 23, 1907.3

Even if the clause in question were susceptible of the construction placed upon it by Mr. Bigelow, there is no doubt that a very large proportion of the citizens of Cincinnati are firmly of the opinion that the power of revocation should not be exercised by the general assembly, as such exercise would be unconscionable and unmoral. Such action they maintain would amount to the repudiation of a solemn obligation and the confiscation of private property. If the terms of the franchise have been violated by the street railway company, resort to an action of forfeiture is, in their opinion, the proper remedy. If the city deems it desirable to acquire the property and no satisfactory agreement of purchase can be arrived at, the institution of condemnation proceedings is, in their judgment, the only legal and just course to pursue. These are the views entertained by many of Cincinnati's most important and most influential civic and business organizations. By impassioned appeals, however, Mr. Bigelow was able to bring some of the labor organizations as well as a few other associations to the support of his revocation measure.

Notwithstanding the introduction of the Bigelow bill Mayor Hunt persisted in his efforts to reach an agreement with the traction company that would, in his judgment, give to the city of Cincinnati as good transportation facilities as are enjoyed by any American municipality. Under the terms of the settlement which was finally concluded, the valuation of the entire street railway system is to be arrived at in the following manner: The sum of $\$ 18,738,950$-the amount of the capital stock of the lessor company-is to be allowed without further question. Without this concession no amicable settlement whatever could have been effected, as the lessee company was under obligation to pay 6 per cent interest upon this amount to the lessor company. The amount actually expended by the lessee company in betterments is to be ascertained by a board of appraisers and also allowed, but in no event can this amount exceed the sum of $\$ 9,716,286$. Should this entire estimate be allowed, the total valuation of the property would be $\$ 28,455,236$. In consideration of the city's agreement to permit the company to earn 6 per cent on the valuation finally fixed by the board of arbitrators, the street railway company has

207 U. S., 584. 
agreed to a surrender of its fifty-year franchise and the substitution therefor of an indeterminate grant. The city is to have the right to purchase the property at the end of any five-year period at the valuation fixed by the arbitrators. All matters relating to service are to regulated by the city. Although the cash fare is to remain 5 cents, the company is required to sell six tickets for a quarter. Universal transfers must be granted. The city is to build the rapid transit loop and the traction company is to lease and operate it and to pay a rental therefor which will meet the interest and sinking fund charges on the bonds issued to defray the cost of improvement. The rate of fare on the rapid transit loop is to be 5 cents including transfers to the surface cars of the entire system. Surplus profits in the operation of either the loop or surface cars are to be divided between the city and the traction company. Fares are to be revised every five years.

Before this tentative agreement goes into effect, it will have to be ratified by a vote of the electors of Cincinnati. No date has yet been fixed for the submission of the question to the voters of the city.

When the proposed settlement between the city and the traction company was reached the general assembly was still in session and the fate of the Bigelow bill was still a matter of conjecture. The measure received a very large vote in the house, but died in the committee of the senate to which it had been referred.

Since the defeat of his revocation measure Mr. Bigelow has been more active than ever in his fight against the traction company. He has organized and is president of a municipal ownership league. By means of this league he hopes to be able to prevent a ratification at the polls of the tenative agreement arrived at between the administration and the traction company. If he accomplishes this end he will bend his efforts to bring about the acquisition by the city of the street railway system through condemnation proceedings. He proposes that the city shall not merely own, but also operate its traction lines.

Mr. Bigelow has rallied support to his plan mainly on account of his charge that the collection of a 5-cent fare is robbery, and by his emphatic assurances that under municipal ownership and operation the rate of fare in Cincinnati would not exceed $\mathbf{3}$ cents. The argument constantly advanced by Mr. Bigelow is that inasmuch as street railway transportation is furnished to the citizens of Cleveland at a 3-cent rate, there is no reason why the people of Cincinnati should not enjoy an equally low fare. The soundness of this contention is certainly open to serious question. By advocates of the traction settlement favored by Mayor Hunt, Mr. Bigelow's reasoning is regarded as absurd and ridiculous. They charge him with making promises impossible of fulfilment for the sole purpose of alluring ignorant voters to accomplish the defeat of the trac- 
tion settlement plan recommended by the administration. Attention is called to the fact that Cincinnati is confronted by conditions that vary materially from those that prevail in the city of Cleveland. Cleveland is level, whereas Cincinnati is made up largely of hills, many of which are very steep. To mount these hills inclined planes which increase the cost of operation are essential. Cleveland has nothing of the sort to contend with. Heavier motors and more current are required to operate Cincinnati's cars. By reason of the steepness of the grades, accidents are much more likely to occur. The use of trailers is impossible. That these conditions tend materially to increase the cost of operating the system must be admitted. Then again Cleveland is a city of forty-seven square miles, whereas Cincinnati covers an area of seventy square miles. Under Cincinnati's universal transfer system passengers may ride from eighteen to twenty miles for 5 cents. The average haul in Cincinnati is undoubtedly much greater than in Cleveland. Another very important factor is that Cleveland has a population approximating 600,000 , while Cincinnati's population is less than 400,000 . During the decade between 1900 and 1910 the increase in Cleveland's population was about 47 per cent, whereas that of Cincinnati increased but 11.5 per cent during the same period. It certainly must be admitted that these widely different circumstances must be taken into consideration in any just determination of reasonable rates of fare. In the opinion of many who have made a careful study of the question, the six-for-a-quarter rate to which the Cincinnati Traction Company has agreed, is, under all the circumstances, a more reasonable charge than the 3-cent rate that now prevails in the city of Cleveland.

One of the grounds upon which Mr. Bigelow bases his vigorous opposition to Mayor Hunt's plan of settlement is the valuation of the traction system which has been tentatively agreed to. In his judgment this valuation is many millions higher than it should be. His estimate of the value of the entire property is but $\$ 14,000,000$.

In order to test the accuracy of Mr. Bigelow's promise that under municipal ownership and operation the charge for transportation would not exceed 3 cents, let it be assumed that the city might acquire the entire street railway system without the expenditure of a dollar. The cost of operation, excluding taxes, for the year 1912, was about $\$ 2,700,000$. To this must be added the taxes which the company was required to pay and which aggregated approximately $\$ 700,000$. The total cost of operation last year was, therefore, $\$ 3,400,000$. To this figure should be added at least $\$ 500,000$ in order to provide for the payment of wages in accordance with the standard Mr. Bigelow deems but fair and just. The cost of operation would thereby be increased to $\$ 3,900,000$. Better servicemore cars, more employees, more power, more wear and tear-would re- 
quire an additional annual outlay. During the year 1912 the company carried about 100,000,000 passengers. At a 3-cent fare a gross income of $\$ 3,000,000$ would be produced. This calculation demonstrates that without any allowance whatsoever for better service and without any provision whatsoever for interest on capital invested or on the mere physical value of the property, the cost of operating the system, under Mr. Bigelow's plan, would result in an annual deficit of about $\$ 900,000$.

Among the obstacles that have confronted Mayor Hunt in his relentless fight to secure better transportation facilities was the strike of the conductors and motormen of the traction company which occurred during the latter part of May and for which Mr. Bigelow was largely responsible. Fortunately the strike lasted for but a brief period. Through the efforts of Mayor Hunt and others, arbitration of all differences between the traction company and its employees was agreed to within ten days. The fact that Mr. Bigelow made no effort whatever to bring about the prompt and amicable settlement which was effected should be borne in mind. That the strike was so speedily terminated was undoubtedly a great disappointment to him.

At present writing a campaign for a new city charter is waging in Cincinnati. Within a few days the voters of the municipality will determine whether or not a new charter shall be formulated and to whom the task of drafting the instrument shall be entrusted. Fifteen charter commissioners are to be chosen. Two tickets have been nominated; one of them by Mr. Bigelow and which is known as the "Civic and Labor Ticket" and the other by the Chamber of Commerce, Business Men's Club, Federated Improvement Association, City Club, Taxpayers' Association and citizens generally, and known as the "Citizens' Ticket." Immediate municipal ownership and operation of all public. utilities has been the principal appeal for support advanced by the candidates on the Bigelow ticket. The fifteen men who are opposing Mr. Bigelow's candidates believe that a new charter is needed and that the municipality should have power to acquire and operate all public utilities but are not in favor of immediate municipal ownership and operation. There is also a strong movement against making any change in Cincinnati's form of government at the present time.

Just how Cincinnati's traction problems are to be solved will depend largely upon the result of the approaching charter election. 